\title{
Analysis of Students' Concepts Understanding Ability in Mathematical Through the Application of Geogebra-Assisted Guided Discovey Learning Model
}

\author{
Muhammad Ashari Lubis Asrin Lubis Mulyono \\ Mathematics Education, Postgraduate School, State University of Medan
}

\begin{abstract}
Concepts understanding ability in mathematical is one of the important goals in learning mathematics. The purpose of this study was to analyze of concepts understanding ability in mathematical of State High School 1 Aek Kuasan students and to find out the difficulties of concepts understanding ability in mathematical of students at SMA Negeri 1 Aek Kuasan. This research is a research with an approach in research using a qualitative approach. This research was conducted at State High School 1 Aek Kuasan whose implementation took place in the even semester of the 2020/2021 academic year. From the research findings, it was found that the concepts understanding ability in mathematical and independent learning of State High School 1 Aek Kuasan students after being taught using the geogebra-assisted guided discovery learning model was in the low category as many as 4 people $(22,22 \%)$. There were 5 students in the medium category $(27,78 \%)$, and 9 students in the high category $(50 \%)$.
\end{abstract}

Keywords: concepts understanding ability mathematical, guided discovery learning models, geogebra

DOI: $10.7176 / \mathrm{JEP} / 12-32-04$

Publication date: November $30^{\text {th }} 2021$

In the world of education, mathematics is one of the subjects that plays an important role in helping develop students' potential. This is as stated by Mahanta (in Uyun, 2016) that "learning mathematics is considered very important in every country in the world. This is because studying mathematics can help students to think and examine things logically and systematically.

Besides that, mathematics is a science with concepts that are arranged hierarchically, structured, logically, and systematically starting from the simplest concepts to the most complex concepts. For this reason, learning mathematics must be done continuously, meaning that it is continuous and not discontinuous. The interrelationships between one material concept and another are evidence of the importance of concepts understanding ability mathematical. Therefore, students should be given more opportunities to see the connections with other materials. It is intended that students can understand mathematics material in depth. If students are able to understand mathematical concepts in depth, then the next student must have been able to solve problems and be able to apply the learning. Hudojo (2005) also revealed that "to be able to understand the structures and relationships, of course it is necessary to understand the concepts contained in mathematics".

However, in reality, the mathematical ability of students in Indonesia is still low. This fact is as expressed by Hasratuddin (2010) that "Judging from student learning outcomes in mathematics from elementary school (SD) to senior high school (SLTA) it is always below the average of other fields of study". In line with this, Rahmawati (2014) revealed that "the achievement of student achievement in mathematics has not been very satisfactory". This is reinforced by Sundayana (2013) which states that there are still many students who feel mathematics is a difficult, unpleasant subject, even a frightening specter, and there are still many students who have difficulties in doing math problems. This has an impact on the low learning outcomes of students' mathematics.

From this, it can be said that the achievement of Indonesian students in mathematics is still considered low. This can be seen from the results of Trends in International Mathematics and Study (TIMSS) reporting on the achievement in mathematics of Indonesian students in 2003, Indonesia was ranked 35th out of 46 participating countries with an average score of 411, while the average international score was 467. In the 2007 TIMSS study results, Indonesia was ranked 36 out of 49 participating countries with an average score of 397, the 2011 TIMSS study results, Indonesia was ranked 38 out of 42 participating countries with an average score of 386 , while the average score international 500 (P4TK, 2011).

In addition, according to Tohir (2019) that the PISA results in 2018 decreased compared to 2015. Regarding the mathematics category, Indonesia was ranked 73rd with an average score of 379 (Tohir, 2019). The low mathematics rating obtained by Indonesia is the focus of problems in Indonesian education.

One of the mathematical abilities that need to be developed among students is the ability to understand students' mathematical concepts. This can be seen from the Regulation of the Minister of National Education No. 22 of 2006 (Permendiknas, 2006) it is stated that school mathematics learning aims for students to have the following abilities: (1) Understanding mathematical concepts, explaining the interrelationships between concepts 
and applying concepts or algorithms in a flexible, accurate, efficient, and precise way in problem solving; (2) using reasoning on patterns and traits, performing mathematical manipulations in making generalizations, compiling evidence, or explaining mathematical ideas and statements; (3) solving problems which include the ability to understand problems, design mathematical models, complete models, and interpret the solutions obtained; (4) communicating ideas with symbols, tables, diagrams, or other media to clarify the situation or problem; (5) have an attitude of appreciating the usefulness of mathematics in life, namely curiosity, attention, and interest in learning mathematics, as well as a tenacious and confident attitude in problem solving.

From the explanation above, it is known that the ability to understand concepts is one of the most important mathematical skills or abilities in achieving the objectives of learning mathematics. In line with this, according to Wakapenda (in Pasaribu, 2016) "understanding is one of the most important traits associated with the attainment of educational goals". Which means understanding is one of the most important characters related to educational attainment goals. A good understanding of concepts will also affect students' mathematical power. If students can understand mathematical concepts well, then students can analyze problems and are able to solve problems. This is in line with what was stated.

According to Annajmi (2016) students have the ability to understand concepts if students are able to (1) explain concepts or are able to re-express what has been communicated to them. (2) Using the concept in a variety of different situations, and (3) Developing several consequences of the existence of a concept. The same thing is explained (Depdiknas, 2006) in the first mathematics learning objective that concept understanding is the ability of students to understand mathematical concepts, explain the interrelationships between concepts and apply concepts or algorithms, in a flexible, accurate, efficient, and precise way in problem solving.

Many factors affect the ability to understand mathematical concepts in learning mathematics, namely learning motivation in this case related to student activities while studying. Lack of students' ability to understand the practice questions. In addition, students are not used to presenting their work. (Priyambodo, 2016).

In learning, understanding concepts is a very important thing that students must have. If the basic concepts received by students are wrong, then it is difficult to improve again, especially if it has been applied in solving math problems. Understanding the concept will provide convenience in increasing students' mathematical procedural knowledge. Because procedures without a conceptual basis are just rules without reason which will lead to errors in mathematics.

To improve the ability to understand students' mathematical concepts at school, a learning model that supports both of these is needed. In line with that, the learning process lies entirely with the teacher as a planner, manager and implementer of learning in schools. Teachers are educational personnel who directly carry out these educational activities. So it can be concluded that the implementation of national education goals in schools lies in the hands of teachers. But in fact teachers often teach lesson materials in the form of conventional learning so that the ability to understand students' mathematical concepts does not increase. Dimyanti \& Mudjiono (2006) state that competent teachers will be better able to create an effective learning environment and will be better able to develop their profession through the use of multiple models, methods, strategies, tips, methods and techniques in teaching learning materials, so that students obtain brilliant results. , both in the form of cognitive, affective, and psychomotor domains.

According to Bruner, the purpose of the Discovery Learning strategy is to give students the opportunity to become a problem solver, scientist, historian or mathematician. Through these activities, students will master the material, be able to apply, and find things that are useful for themselves. Learning through Guided Discovery Learning has a good learning concept. This is in line with what Suprihatiningrum (2013) said that "Model Guided Discovery Learning is learning in which students can find previously unknown concepts independently guided by the teacher".

In order to improve student learning outcomes, teachers are expected to always try to design and implement learning in order to create innovative and creative learning, especially by using media. Students are given the opportunity to be directly involved in scientific activities and experiences that lead to the formation of scientific cognition. Good learning outcomes will be obtained if students are able to invest the knowledge they have gained through direct observation and experience (Dale in Arsyad, 2000). One of the media that can be used is computer-based teaching media with Geogebra software.

Learning with geogebra can accommodate students who are slow to receive lessons, because it can provide an effective climate in a more individual way, never forget, never get bored, and can stimulate students to do exercises. In addition, the use of geogebra as a learning media can make it easier for teachers to convey material, make it easier for students to absorb what the teacher says, and simulations occur because of the availability of animation and manipulation movements (dragging) that can provide a clearer visual experience to students.

Based on these problems, the authors are interested in conducting research with the title "Analysis of Concept Understanding Ability through Application of Geogebra Assisted Guided Discovery Learning Model" 


\section{METHOD}

\section{Research design}

Field observations were carried out to deepen students' ability problems as research subjects. The research instrument that was arranged was adjusted to the formulation of abilities obtained from the conclusions of field observations. The instruments compiled consist of the ability to understand mathematical concepts and learning tools. The Mathematical Concept Understanding ability instrument is structured to get a complete picture of students' ability to understand mathematical concepts. While the learning tools are arranged in relation to conditioning students to understand mathematical concepts and learn independently. To ensure that the instruments and learning tools that are prepared are in accordance with the abilities designed as a result of field observations, the accuracy of the instruments and learning tools is validated. Learning using the GeoGebraassisted Discovery Learning model is intended to condition research subject students to get used to understanding mathematical concepts and using them in solving mathematical problems. The implementation of this activity is carried out after the entire series of learning activities using the Guided Discovery Learning model assisted by GeoGebra has been completed. The test activities and filling out the questionnaire were carried out honestly and transparently, the answer sheets were corrected, and analyzed using the Miles and Huberman model including: data collection (data collection), data reduction (data reduction) the results of the concept understanding ability test and learning independence questionnaire, data presentation (data display), and conclusions (conclusion) and verification (verification). Interviews were conducted on the research subject students based on the results of the assessment of students' answers to the mathematical concept understanding ability test. Interviews with teachers were conducted to obtain comparative data on the assessment descriptions of students' answer sheets and the results of the descriptions of interviews with students (data triangulation). Data analysis was carried out after the test and triangulation activities were completed. Data analysis was carried out in the form of quantitative descriptions and qualitative descriptions to produce research findings and draw conclusions. Research results in the form of a description of the answers to the formulation of the problem posed in this study. From the results of this description, a discussion is carried out by comparing it to theories and other similar research results to get a broader picture of understanding mathematical concepts and their relation to student learning independence. This description of the results and discussion will produce conclusions from the research conducted. The following is a chart in this study depicted as Figure 1.

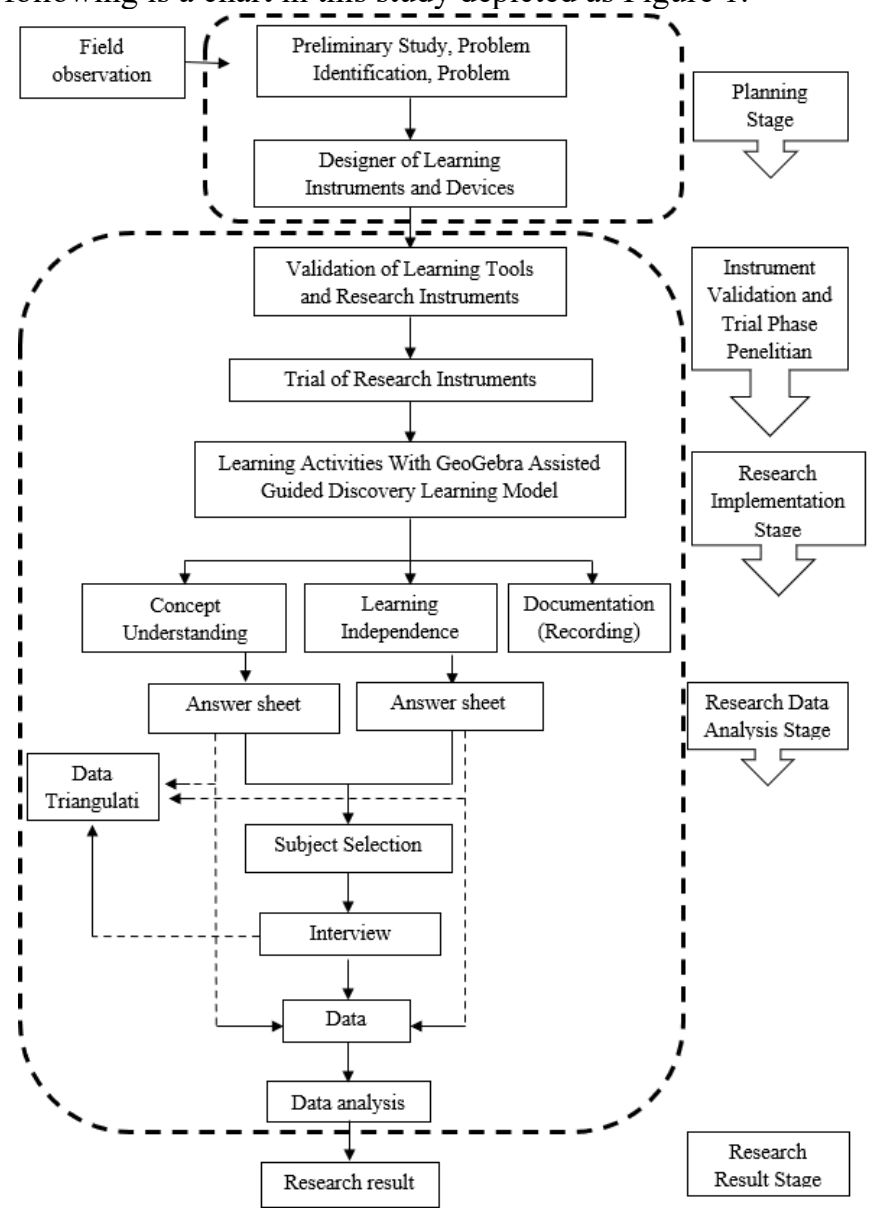

Figure 1. Research Design 


\section{Research Instruments}

The instrument used to measure the ability to understand mathematical concepts is a written test. This test was given after the GeoGebra-assisted guided discovery learning model was implemented. This test is structured referring to the indicators of the ability to understand mathematical concepts. Many of the questions used in this instrument are 5 items in essay form.

Research Subjects and Objects

The subjects of this study were 18 students of 10th grade students of Aek Kuasan 1 State High School as many as 18 students. While the object of this research is the analysis of the ability to understand mathematical concepts and independent learning through the application of the GeoGebra-assisted Guided Discovery Learning model.

\section{RESULTS AND DISCUSSION}

\section{a) Description of Students' Mathematical Concept Understanding Ability}

The value of the test results of students' mathematical concept understanding abilities obtained from 18 people was described statistically spread over 3 criteria, namely low, medium, high. The distribution of students' mathematical concept understanding abilities is presented in Table 1.

Table 1. Test of Students' Mathematical Concept Understanding Ability Level

\begin{tabular}{ccccc}
\hline No & Value Interval & $\begin{array}{c}\text { The number } \\
\text { of students }\end{array}$ & Percentage & Rating Category \\
\hline 1 & $70 \leq \mathrm{AUMC} \leq 100$ & 9 & $50 \%$ & High \\
\hline 2 & $55 \leq \mathrm{AUMC}<70$ & 5 & $27,78 \%$ & Medium \\
\hline 3 & $0 \leq \mathrm{AUMC}<55$ & 4 & $22,22 \%$ & Low \\
\hline
\end{tabular}

Note: $A \overline{U M C}=$ Ability to Understand Mathematical Concepts.

Based on Table 1. shows that students with the ability to understand mathematical concepts in the low category are 4 people $(22.22 \%)$. There were 5 students in the medium category $(27.78 \%)$, and 9 students in the high category (50\%). From the description of this distribution, it can be concluded that the level of students' ability to understand mathematical concepts is mostly in the high category.

b) Analysis of Difficulty in Solving Students' Mathematical Concept Understanding Ability Problems in Mathematics

Analysis of Difficulty in Solving Problems in Students' Mathematical Concept Understanding Ability High Criteria

Based on the answer sheet of the concept understanding ability test, S-1 and selected as students were analyzed qualitatively from students with high criteria. For students with high criteria, namely students who coded S-1 and stated that there were difficulties when taking the students' mathematical concept understanding ability test using the Geogebra-assisted Guided Discovery Learning approach. The excerpts of the interview (Caption: Teacher $=\mathrm{G}$ and Student $=\mathrm{S}$ ) are as follows:

\section{Students with code S-1}

G : good afternoon

S : Good day sir

G : How are you doing?

$\mathrm{S} \quad$ : Healthy sir

$\mathrm{G} \quad$ : Can you ask a question?

$\mathrm{S} \quad$ : Can you sir?

$\mathrm{G}$ : In question number 2, your answer is correct, but why did you not finish point $\mathrm{b}$ ?

$\mathrm{S}:$ : I'm running out of time sir

G : Can you tell me how to solve it?

$\mathrm{S} \quad$ : Yes, sir

G : Try to explain!

S : The elevation angle is the angle formed between the horizontal straight line and the observer's upward position.

G : Then how to calculate it for case number 2 .

$\mathrm{S} \quad$ : By using the ratio of cosine pack, that is $\cos \theta=\frac{A B}{A C}=\frac{x}{y}$

G : Then number 5, why only provide information, why the calculation is not done.

$\mathrm{S} \quad$ : Yes sir, for question number $5 \mathrm{I}$ am confused about how to solve it

G : Ok, thank you son.

$\mathrm{S}$ : You are welcome, sir.

From the interview transcript above, it can be seen that students as subjects have problems in questions number $2 \mathrm{~b}$ and number 5 , which aims to determine the ability to understand students' mathematical concepts in solving problems on trigonometry material. The $\mathrm{S}-1$ answers to questions number $2 \mathrm{~b}$ and number 5 can be seen 
in Figure 4.15 and Figure 4.16 as follows:

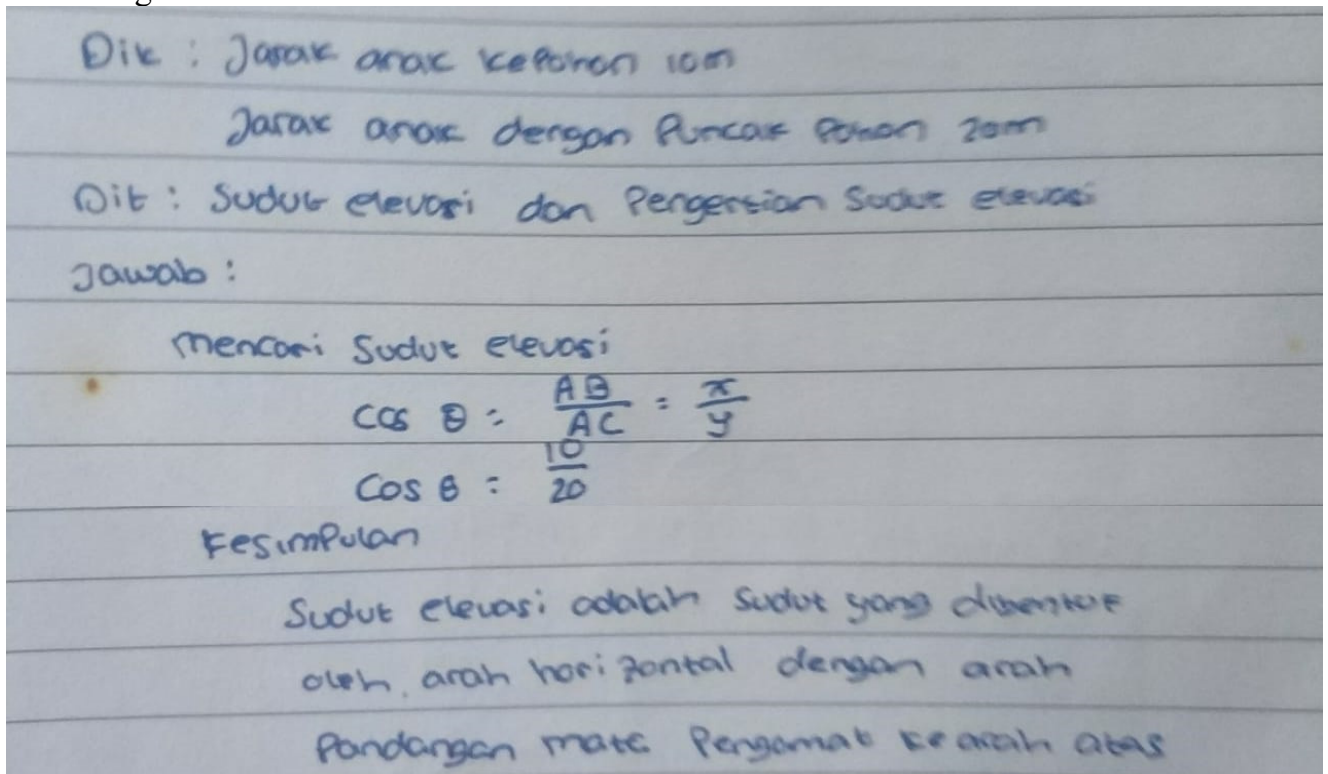

Figure 2. Working on the Mathematical Concept Understanding Ability Test on Problem Number 2 Code S-1

The following are the results of an interview with one of the students about how to solve problems for students who have the ability to understand mathematical concepts of students with moderate criteria.

\section{Students with code S-4}

$\mathrm{G}:$ : good afternoon

S : Good afternoon, Sir

G : Good afternoon, Sir

$\mathrm{S} \quad$ : There is, sir. In question number $3 \mathrm{c}$ and every point a in all questions sir.

G : When taking the test, what's the problem, son?

S : In question number 3c, sir, I don't understand how to calculate the depth of the sea where the anchor falls.

G : What makes you not understand?

S : I don't understand how to multiply it sir,

G : That's how it looks, then in point a, what are the problems, son?

S : I am confused, sir, what kind of information should I write in the answer.

G : Why are you confused, you just need to write down all the information about the story.

S : Ok sir, now I understand.

G : How do you think you will solve it?

$\mathrm{S} \quad$ : By writing down what is in the question sir, for example in point a in question number 2, the information that is known is the distance of the tree is $10 \mathrm{~m}$, the distance between the child and the treetop is $20 \mathrm{~m}$, and what is being asked is the angle of elevation.

$\mathrm{G} \quad$ : ok thanks son?

$\mathrm{S}$ : Yes sir

From the interview transcript above, it can be seen that students as subjects have problems with number $3 \mathrm{c}$ and point a in each question, which aims to determine the ability to understand students' mathematical concepts in solving problems on trigonometry material. The answers for S-4 are as follows: 


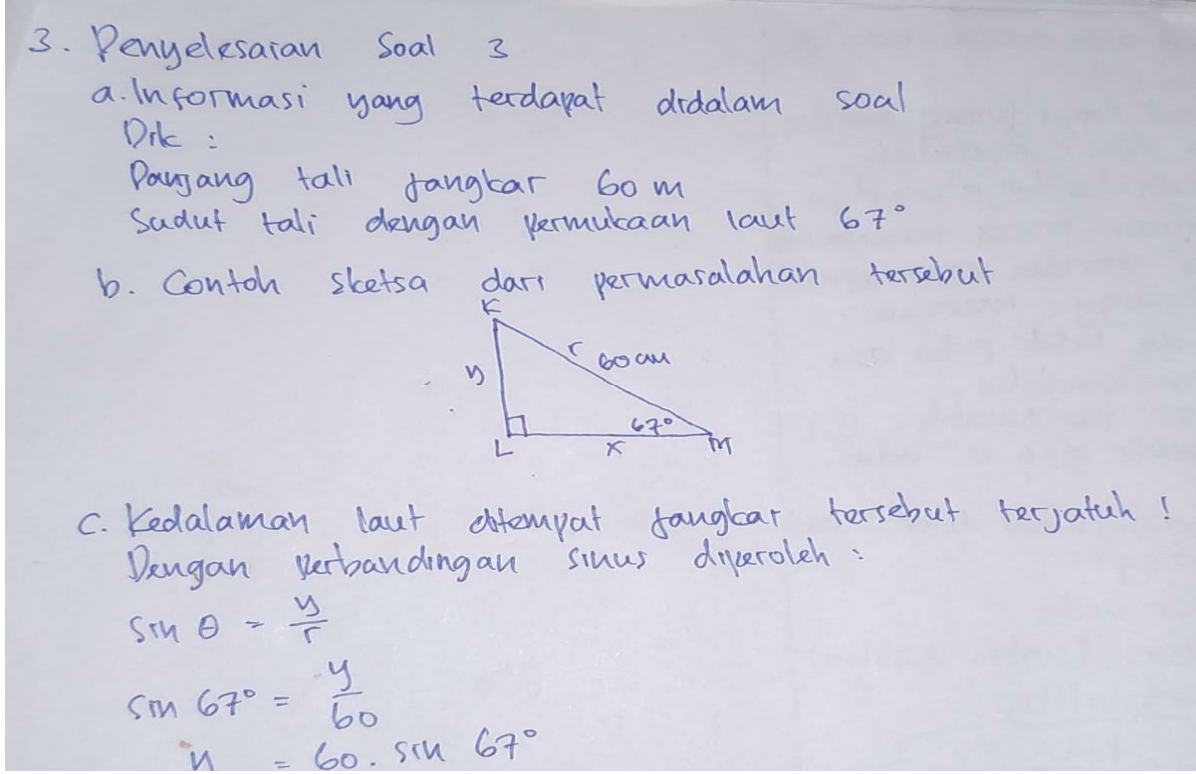

Figure 3. Working on the Ability Test for Understanding Mathematical Concepts S-4 Code

Based on the above, it can be concluded that students with S-4 code have difficulty in restating a concept where students are not able to state the meaning of terms that mark the concept, besides students with S4 code also have difficulty in using concepts in solving problems, where S-1 students cannot perform calculation operations and detect useful information from a concept.

The following is the result of an interview with one of the students about how to solve problems for students who have low Criteria for Students' Mathematical Concept Understanding Ability.

\section{Students with code S-18}

G : good afternoon

S : Good afternoon, Sir

G : Well, my son, in the student's mathematical concept understanding ability test, do you think there are any obstacles that you face, son?

$\mathrm{S} \quad$ : There is, sir. Almost every point $\mathrm{c}$ and number 5 in the problem I can't complete the calculation

$\mathrm{G}$ : When taking the test, what's the problem, son?

$\mathrm{S} \quad$ : In question number 5, sir, I don't know how to solve the algebraic operation, sir.

G : That's how it looks, ok thank you son

$\mathrm{S}:$ : Yes sir

From the interview transcript above, it can be seen that students as subjects have problems in all questions that aim to determine the ability to understand students' mathematical concepts in solving problems on trigonometry material. The answers to $\mathrm{S}-18$ are as follows:

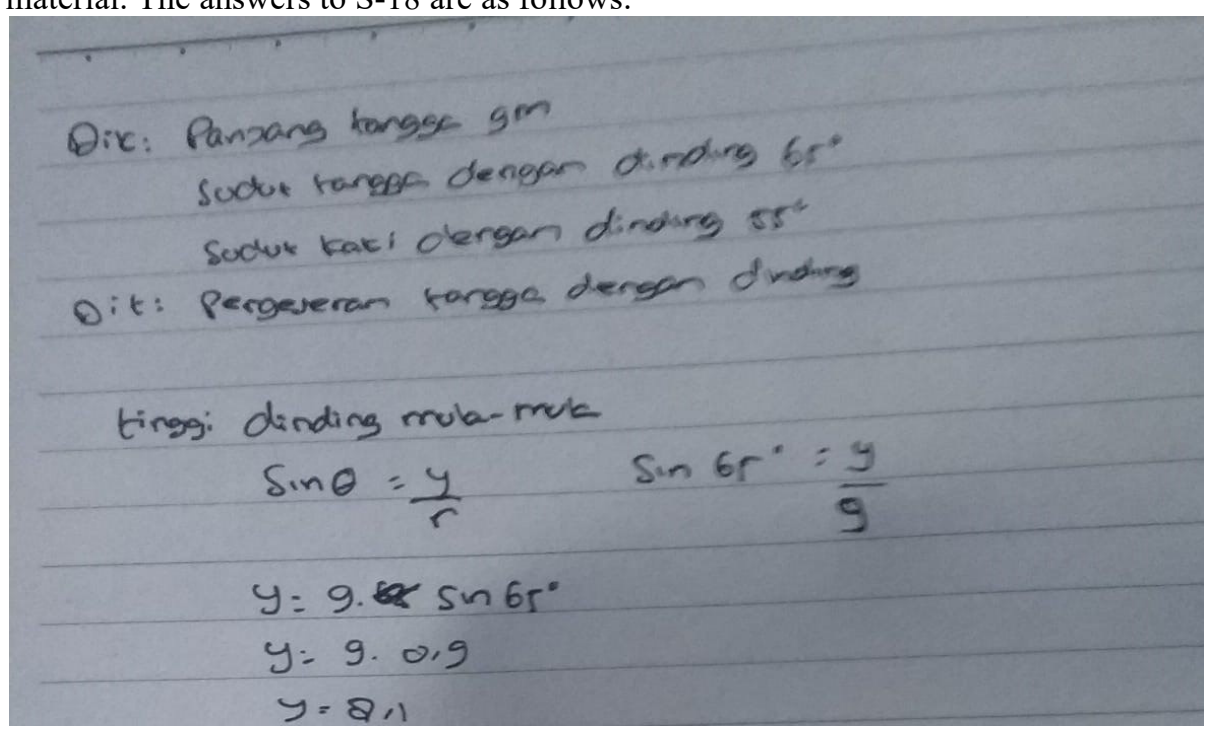

Figure 4. Working on the Ability Test for Understanding Mathematical Concepts Code S-18

Based on the above, it can be concluded that students with the S-18 code have difficulty in citing examples 
and non-examples where students are not able to give examples of certain concepts, and students also experience difficulties with indicators using concepts in solving problems where students with S-codes 18 are unable to perform calculations and deduce useful information from a concept.

This study focuses on the analysis of the process of concept understanding ability and student learning independence. Research conducted by Surur and Oktavia (2019) with the title The Effect of the Discovery Learning Learning Model on Understanding Mathematical Concepts. This research was conducted in class X SMK Khamas Asembagus using the Discovery Learning model. The results showed that the discovery learning model is more suitable for use in mathematics learning for class X students of SMK Khamas Asembagus than the direct teaching model, this is because in the learning process, the use of the discovery model is a learning model that involves many students in teaching and learning activities. Thus, the discovery learning model can be an alternative for mathematics subject teachers in improving student learning outcomes.

According to Annajmi (2016) students have the ability to understand concepts if students are able to (1) explain concepts or are able to re-express what has been communicated to them. (2) Using the concept in a variety of different situations, and (3) Developing several consequences of the existence of a concept. The same thing is explained (Depdiknas, 2006) in the first mathematics learning objective that concept understanding is the ability of students to understand mathematical concepts, explain the interrelationships between concepts and apply concepts or algorithms, in a flexible, accurate, efficient, and precise way in problem solving.

Concept understanding is an ability that becomes the basis for students in doing math (doing math). Having the ability to understand mathematical concepts will make it easier for students to solve problems so that students are expected to be able to present problem solving according to their own ideas without having to focus on only one form of completion. In other words, if someone understands mathematical concepts, they will be able to easily use these concepts in solving mathematical problems and problems in everyday life.

In the process of understanding concepts and independent learning of students, many methods have been developed by teachers, both through the approach of teaching materials, as well as innovations that were originally discovered by themselves. In this study, learning uses a cooperative learning model of Guided Discovery Learning type assisted by geogebra which greatly helps students plan solutions so that they are able to solve problems related to understanding concepts and learning independence. All are directed at the efforts of students to master competence or learning objectives. Learning through Guided Discovery Learning has a good learning concept. This is in line with what Suprihatiningrum (2013) said that "Model Guided Discovery Learning is learning in which students can find previously unknown concepts independently guided by the teacher".

This is in line with Surur and Oktavia's research (2019) that using discovery learning can improve students' understanding of mathematical concepts, this can be seen in the discovery model learning process involving students actively in learning compared to using conventional methods. In line with this, based on research by Artanti and Lestasi (2017) that using the discovery learning model can increase students' independence in learning mathematics, this increase can be seen that students are active in learning independently by looking for sources of knowledge from books and other materials.

In the learning process carried out for four meetings in the class of State High School 1 Aek Kuasan students that the ability to understand concepts and students' independence in learning is getting better after the implementation of the Geogebra-assisted Guided Discovery Learning model compared to previous learning which still uses conventional learning in the form of lectures or explaining theories only. .

\section{CONCLUSION}

Mathematical Concept Understanding Ability and Learning Independence of State High School 1 Aek Kuasan students after being taught using guided discovery learning model assisted by geogebra, namely the low category of 4 people $(22.22 \%)$. There were 5 students in the medium category $(27.78 \%)$, and 9 students in the high category $(50 \%)$. From the description of this distribution, it can be concluded that the level of students' ability to understand mathematical concepts is mostly in the high category. The difficulty of students in answering the ability test for understanding mathematical concepts after being taught using the geogebra-assisted guided discovery learning model is as follows:

a. In the high category, students did not experience significant difficulties in solving the problems given.

b. In the medium category, students have difficulty in restating a concept and using the concept in solving problems.

c. In the low category, students have difficulty in each indicator where students cannot restate a concept, cannot mention examples and non-examples and use concepts in solving problems.

\section{ACKNOWLEDGMENTS}

The authors thank the anonymous reviewers for their helpful suggestions and comments on the previous versions of this article. 


\section{REFERENCES}

Annajmi. (2016). Peningkatan Kemampuan Pemahaman Konsep Matematik Siswa SMP melalui penemuan terbimbing berbantu software geogebra. MES (Journal of Mathematics Education and Science), 2(1):1-9. https://doi.org/10.30743/mes.v2i1.110

Arsyad, A. (2000). Media Pengajaran. Jakarta:Rajawali Press.

Artanti, F \& Lestari, T. K. (2017). Upaya Meningkatkan Kemandirian Belajar Matematika Siswa Dengan Menggunakan Model Discovery Learning Di Man 3 Yogyakarta. PROSIDING

Depdiknas. (2006). Standart isi mata pelajaran matematika tingkat sekolah dasar dan menengah. Jakarta : depdiknas

Dimyati \& Mudjiono. (2006). Belajar dan Pembelajaran. Jakarta: Rineka Cipta.

Hasratuddin. (2010). Meningkatkan kemampuan berpikir kritis dan kecenderungan emosional siswa SM melalui pendekatan matematik realistik. Disertasi

Hudojo, H. (2005). Pengembangan Kurikulum dan Pembelajaran Matematika. Malang: UM Press.

Pasaribu, E. Z. (2016). Peningkatan Kemampuan Pemahaman Dan Disposisi Matematis Siswa Melalui Model Pembelajaran Penemuan Terbimbing Di Mtsn 1 Padangsidempuan. Tesis. Paradikma. Vol 9 no 2

P4TK (Pusat Pengembangan dan Pemberdayaan Pendidik dan Tenaga Kependidikan Matematika). 2011. Instrumen Hasil Belajar Matematika SMP: Belajar dari PISA dan TIMSS.Jakarta: P4TK Kemendikbud

Priyambodo, S. (2016). Peningkatan Kemampuan Pemahaman Konsep Matematis Siswa dengan Metode Pembelajaran Personalized System of Instruction. Jurnal "Mosharafa", Volume 5, Nomor 1, Januari 2016. https://journal.institutpendidikan.ac.id/index.php/mosharafa /article/view/mv5n1 2/260

Rahmawati, A. 2014. Meningkatkan Kemampuan Pemahaman Matematika Siswa SMP Melalui Metode Penemuan Terbimbing. Prosiding Seminar Nasional Pendidikan Matematika Program Pascasarjana STKIP Siliwangi Bandung, Vol 1, ISSN 2355-0473

Surur, M \& Oktavia, S. T. 2019. Pengaruh Model Pembelajaran Discovery Learning Terhadap Pemahaman Konsep Matematika. JPE (Jurnal Pendidikan Edutama) Vol. 6 No. 1 Januari 2019. http://dx.doi.org/10.30734/jpe.v6i1.341

Sundayana, R. 2013. Media Pembelajaran Matematika. Bandung : Alfabeta

Suprihatiningrum, J. (2013). Strategi Pembelajaran : Teori Dan Aplikasi. Yogyakarta: Ar-Ruzz Media

Tohir, M. (2019). Hasil PISA Indonesia Tahun 2018 Turun Dibanding Tahun 2015. Tersedia Online: https://matematohir.wordpress.com/2019/12/03/hasil-pisa-indonesiatahun-2018-turun-dibanding-tahun2015/ [03 Desember 2019]

Uyun, M, dkk. (2016). Eksperimentasi Model Pembelajaran Kooperatif Tipe Teams Game Tournament (Tgt) Dan Team Assisted Individualization (Tai) Dengan Pendekatan Saintifik Ditinjau Dari Kecerdasan Logis Matematis Siswa Kelas Vii Smp Negeri Se-Kabupaten Karanganyar Tahun Pelajaran 2014/2015. Jurnal Elektronik Pembelajaran Matematika. Vol.4, No.7, hal 668-678. https://jurnal.uns.ac.id/jpm/article/view/10820/9696 